\section{The use of voice in higher education: What the professors have to say?}

\author{
Yuri Patrick Oliveira de Medeiros ${ }^{1}$ \\ https://orcid.org/0000-0002-4993-5355 \\ Cynthia Maria Barboza do Nascimento ${ }^{1}$ \\ https://orcid.org/0000-0001-9197-2136 \\ Adriana de Oliveira Camargo Gomes ${ }^{1}$ \\ https://orcid.org/0000-0002-1871-9502 \\ Zulina Souza de Lira ${ }^{1}$ \\ https://orcid.org/0000-0002-8413-5513 \\ Ana Nery Araújo ${ }^{1}$ \\ https://orcid.org/0000-0001-7887-6246
}

Universidade Federal de Pernambuco UFPE, Recife, Pernambuco, Brasil.

Conflict of interests: Nonexistent

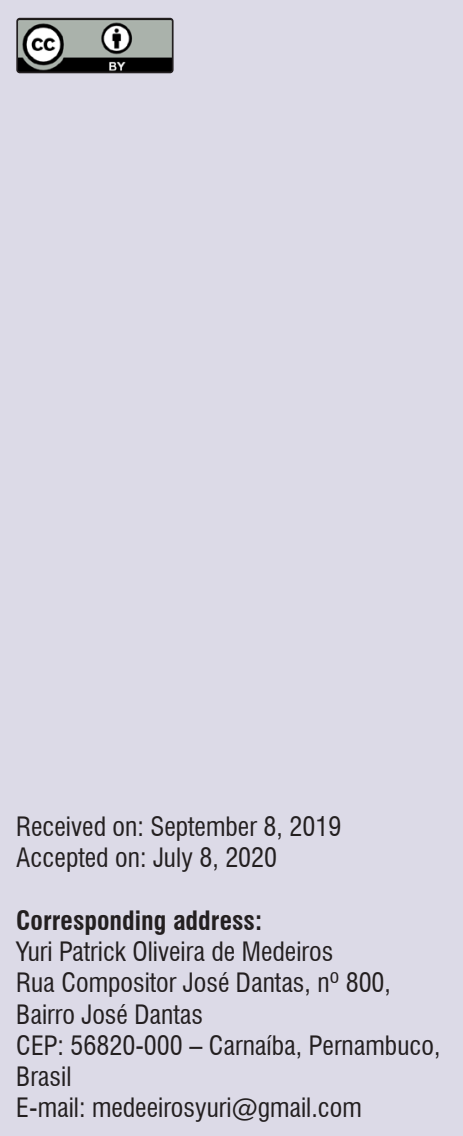

\section{ABSTRACT}

Purpose: to describe the perception of university professors regarding their use of voice at work.

Methods: a total of 247 higher education professors participated in this study. They answered a questionnaire on voice complaints, in which three complaints or more were considered indicative of a voice disorder. After the professors with a potential voice disorder were identified, a conversational interview was conducted with five professors to learn more on their perceptions on the use of voice at work. The study was approved by the research ethics committee of the institution of origin. The data were quantitatively and qualitatively analyzed.

Results: the age group 20 to 30 years old was the one that most presented voice problems. The most recently hired professors (up to five years of work), with a 40-hour weekly workload, were those who most reported voice complaints. The professors had a good perception of their voice and demonstrated good knowledge about it.

Conclusion: although voice complaints were prevalent, the professors proved to be aware of how to take care of their voices.

Keywords: Speech, Language and Heraing Sciences; Voice; Faculty; Occupational Health; Communication 


\section{INTRODUCTION}

Occupational voice users are those who depend on their voice to work and are negatively impacted if their voice is changed. In present-day society, approximately one third of the professionals rely on their voice to work ${ }^{1}$, including teachers, professors, singers, actors and actresses, clergies, politicians, secretaries, lawyers, health professionals, salespeople, street vendors, and community health agents, just to name a few. However, the professionals who most use their voice to work are teachers and professors ${ }^{1-3}$.

The voice is particularly important to make possible the teachers' and professors' work. They are expected to project well their voice, with precise articulation, pneumophonoarticulatory coordination, good sonority, and adequate rhythm and speed, thus delivering a proper oral communication ${ }^{2,4}$.

Dysphonia is considered an important health disorder, with direct consequences not only to health but also to the person's social and professional life. Teachers and professors have two to three times more complaints of dysphonia than other professionals, which evidences that teaching is an occupation with a high risk of this affection ${ }^{5,6}$.

Occupational voice disorders are normally associated with how teachers and professors use the voice: usually, they increase vocal intensity when they speak for a long time and tension the cervical musculature, most of the time not being attentive to wellbeing ${ }^{7,8}$; moreover, the work setting and work-process organization together can be significant factors for voice disorders. This triad - person, work setting, and work organization - was established by consensus for the development of a document that included occupational voice disorders (OVD) in the occupational-related diseases manual ${ }^{2}$.

Voice disorders keep teachers and professors from effectively performing their duties. As a result, they may be recurrently absent from work, ask leaves of absence, or even quit the profession altogether. Hence, they must know their voice, its qualities and limitations, and the outcomes of using it during class ${ }^{9-11}$.

The person's awareness of the factors that lead to an unhealthy voice, their knowledge of how the voice works and how to handle it at work, and their vocal habits are especially important. Having no access to information or being unable to put their knowledge about voice into practice due to an inadequate work setting and/or organization can contribute to the onset of voice symptoms ${ }^{12,13}$.
Most of the studies refer to elementary, middle, and high school teachers as those who most have voice problems. However, few approach university professors. Higher education professors may have somewhat different working conditions when compared with other teaching levels, considering the work setting and organization. Nonetheless, their voice is not free from risks related to the environmental, organizational, and personal factors inherent to their profession ${ }^{14}$.

The use of voice in higher education is a pertinent theme, which calls for a reflection on how this category needs to be cautious in their professional use of the voice. This applies particularly to the awareness of the importance of the university professors' selfperception of voice, as they grow conscious of their health and professional performance ${ }^{2}$. Hence, this study's differential is its analysis based on the identification of the most reported voice complaints and the professors' statements - this research's main thread. Given the above, this study aimed to identify the most reported voice symptoms and describe how university professors perceive the use of voice in their work.

\section{METHODS}

This was a quantitative, qualitative, descriptive, observational, cross-sectional study. The research was carried out in a public university, counting with the participation of 247 professors working in the university's academic departments.

This research was approved by the Human Research Ethics Committee of the Universidade Federal de Pernambuco, PE, Brazil, under protocol number 029245/2015. The data collection took place at two different stages: first, with an online questionnaire sent to all the 2,504 professors of the three campuses. In this stage, the inclusion criterion was to be either a tenured or substitute professor, with or without voice complaints, invited through digital media to participate in the research. The exclusion criteria for this study were the professor's not having an active e-mail and/or not completely answering the questionnaire.

For this stage, the collection instrument used was a questionnaire whose questions are shown in Figure 1. It was developed by the authors and sent online to the professors of the university's academic departments to identify professors with complaints of changes in their voice. A minimum of three complaints was defined as indicative of a potential communication disorder; this cutoff score was based on the study by Sapir ${ }^{15}$. 
A total of 247 professors answered the questionnaire. Based on this sample, the exclusion criterion for the second stage of the research was the professors who had less than three voice complaints. Since the individuals with three or more such complaints can have some voice disorder ${ }^{15}$, these were the relevant ones for this study.

When the researchers sent the questionnaire online to the participants, they also provided all the explanations regarding the study. This included clarifications about the structure of the informed consent form, which was developed in compliance with the norms of the Ethics Committee and then made available on the internet along with the questionnaire. Since it was an electronic questionnaire, its being answered and returned characterized that the participants were informed and consented with it.

The initial questionnaire - in which the professors with a potential voice disorder were identified - were quantitatively analyzed, pointing out the aspects of the voice-related problems reported by the group. Then, they were contacted and invited to participate in the second stage of the research, with an individual interview aimed to investigate how they perceived the use of voice at work. It contained questions regarding voice representation at work and factors that led to voice complaints (including personal, organizational, and environmental aspects of their work).

When contacted, the professors were asked about the best place where they could meet for the interview. Hence, the authors offered to go where the professors proposed. Only five professors agreed to be interviewed, as most did not have time available. The interview was recorded on audio and transcribed, which was used for the analysis along with the notes taken. Since the sample in qualitative studies is not based on numerical criteria, the number of interviews that allowed a certain repetition of information (saturation of the theme) was considered enough. Thus, after the fifth interview, the collection was finished; the theme was being saturated, as the content reported in each professor's interview was being recurrently repeated in every new collection.

The quantitative analysis of the results used descriptive statistics techniques, with tabulated absolute and percentual distributions.
The interviews and the meaning of the statements contained in them were analyzed following Bardin's content analysis method. It organizes the interviewees' statements by thematic categories, based on the central meaning of communication. These, depending on their presence and the frequency in which they appear, can be meaningful for analytical purposes ${ }^{16}$. The content analysis method comprises three major phases: 1) Pre-analysis, encompassing the general reading of the material chosen for analysis; 2) Exploration of the material - i.e., the excerpts of the texts approached as recorded units and the definition of rules to count, classify, and organize the information into categories; 3) Treatment and interpretation of the results, which consist in picking up the manifested and latent content of all the material collected.

After reading and rereading the material collected, three categories were established, namely: voice representation, factors leading to voice complaints, and recommendations for healthily using the voice at work. Based on these categories and repeatedly reading the interviews, subcategories became increasingly noticeable. It is important to highlight that the categories were already available to the researcher from previous experience and interests; these are predefined, a priori categories in content analysis. The subcategories, on the other hand, had not been preestablished; they arose from what had been expressed in the professors' words, which is valued in content analysis.

\section{RESULTS}

The characteristics of the sample researched are presented in Table 1. Four identification variables are shown in it: age group, gender, time working as a professor, and weekly workload. Most of the study's population were females 20 to 39 years old, having taught at the institution for up to five years, with a 40-hour weekly workload. The professors involved in this research worked in fields related to math, humanities, and health.

As for the characteristics of the professors who agreed to participate in the second stage of the research, four were women and one, man, all of them 40 to 49 years old, with a 40 -hour weekly workload. 
Table 1. Characteristics of the sample researched

\begin{tabular}{lcc}
\hline Variable & $\mathbf{n}$ & $\mathbf{\%}$ \\
\hline TOTAL & $\mathbf{2 4 7}$ & $\mathbf{1 0 0 , 0}$ \\
\hline Age group (years) & 110 & 44.53 \\
20 to 39 years old & 74 & 29.95 \\
40 to 49 years old & 63 & 25.5 \\
50 years old or more & & \\
\hline Gender & 106 & 42.91 \\
Males & 141 & 57.08 \\
Females & & \\
\hline Time working as a professor & 118 & 47.77 \\
Up to 5 years & 64 & 25.91 \\
6 to 10 years & 30 & 12.14 \\
11 to 20 years & 35 & 14.17 \\
More than 20 years & & \\
\hline Weekly workload & 12 & 4.85 \\
20 hours & 235 & 95.14 \\
40 hours & & \\
\hline
\end{tabular}

The assessments of the self-reported voice symptoms are presented in Table 2, according to the identification variables. This table also shows the percentage of professors who reported more than three voice symptoms (which was characterized as a potential voice problem) and those that reported less than three. The analysis revealed that the age group with most voice symptoms is 20 to 39 years old and that such symptoms are reported mostly by female professors. Those who most report symptoms had been working as professors for up to five years, as well as those with a 40-hour weekly workload. The percentage of professors participating in the research who reported three or more voice symptoms was $57.89 \%$.

Table 2. Voice symptoms, according to the identification variables

\begin{tabular}{|c|c|c|c|c|c|c|}
\hline \multirow{3}{*}{ Variable } & \multicolumn{4}{|c|}{ Voice symptoms } & \multirow{2}{*}{\multicolumn{2}{|c|}{ TOTAL }} \\
\hline & \multicolumn{2}{|c|}{ Three or more symptoms } & \multicolumn{2}{|c|}{ Less than three symptoms } & & \\
\hline & $\mathrm{N}$ & $\%$ & $\mathrm{~N}$ & $\%$ & $\mathrm{n}$ & $\%$ \\
\hline Total group & 143 & 57.89 & 104 & 42.10 & 247 & 100.0 \\
\hline \multicolumn{7}{|l|}{ Age group (years) } \\
\hline 20 to 39 years old & 65 & 59.09 & 45 & 40.90 & 110 & 100.0 \\
\hline 40 to 49 years old & 45 & 60.81 & 29 & 39.18 & 74 & 100.0 \\
\hline 50 years old or more & 33 & 52.38 & 30 & 47.61 & 63 & 100.0 \\
\hline \multicolumn{7}{|l|}{ Gender } \\
\hline Males & 54 & 50.94 & 52 & 49.05 & 106 & 100.0 \\
\hline Females & 89 & 63.12 & 52 & 36.87 & 141 & 100.0 \\
\hline \multicolumn{7}{|c|}{ Time working as a professor } \\
\hline Up to 5 years & 66 & 55.93 & 52 & 44.06 & 118 & 100.0 \\
\hline 6 to 10 years & 38 & 59.37 & 26 & 40.62 & 64 & 100.0 \\
\hline 11 to 20 years & 18 & 60.0 & 12 & 40.00 & 30 & 100.0 \\
\hline More than 20 years & 21 & 60.0 & 14 & 40.0 & 35 & 100.0 \\
\hline \multicolumn{7}{|l|}{ Weekly workload } \\
\hline 20 hours & 5 & 41.66 & 7 & 58.33 & 12 & 100.0 \\
\hline 40 hours & 138 & 58.7 & 97 & 41.27 & 235 & 100.0 \\
\hline
\end{tabular}


The voice symptoms reported by the professors are presented in Figure 1. The most recurrent complaint was the discomfort felt when speaking for a long time $(67.13 \%)$. The second most mentioned complaint was the unawareness of how to protect their voice (63.63\%). Also, $45.45 \%$ of the professors reported having perceived changes in their voice, with complaints such as hoarse and/or weak voice, and/or effort to speak, and/or voice cracks. The least reported complaint was of people mentioning that the professor's voice was hoarse $(6.99 \%)$.

\begin{tabular}{|l|c|c|}
\hline Voice symptoms & $\mathbf{n}$ & $\%$ \\
\hline My voice gives me a hard time at work & 28 & 19.58 \\
\hline The noise at the work setting interferes with my oral communication & 39 & 27.27 \\
\hline My voice feels uncomfortable when I speak for a long time & 96 & 67.13 \\
\hline My voice changes throughout the day & 38 & 26.57 \\
\hline I notice changes in my voice, such as hoarseness, weakness, effort to speak, and/or voice cracks & 65 & 45.45 \\
\hline I feel pain, phlegm and/or a globus sensation when I use my voice & 32 & 22.37 \\
\hline I feel my voice tired when I speak & 41 & 28.67 \\
\hline I do not know how to care for my voice & 91 & 63.63 \\
\hline I speak too much at work and it harms my voice & 53 & 37.06 \\
\hline People say my voice sounds hoarse & 10 & 6.99 \\
\hline I have a hard time performing my duties at work because of my voice & 16 & 11.18 \\
\hline I sometimes get distressed because of my voice & 15 & 10.48 \\
\hline
\end{tabular}

Figure 1. Frequency of the voice symptoms

Regarding the professors who participated in the second stage of the research, the self-reported voice complaints that stood out were voice discomfort due to long periods speaking and changes in the voice, with complaints such as hoarse and/or weak voice, and/or effort to speak, and/or voice cracks.

The professors' perceptions regarding voice representation are presented in Figure 2. Three subcategories - communication, professional activity, and interaction with the students - arose from the analysis of the reports. In the communication subcategory, most of the interviewees reported that the voice is the means of communicating with other people: "The voice is indispensable for me because that is how I express myself... It is a means of reaching out to the other people" (P2). In the professional activity subcategory, the professors reported that the voice is important because it is what they use to work with, the common aspect in their statements: "The voice is one of the main resources we have for our work... It is with my voice that I work as a professor" (P1). In the interaction with the students subcategory, the professors reported that it was with the voice that they managed to communicate with the student: "The voice for me is the main means of communication with my student, to expose my ideas" (P4). 


\begin{tabular}{|c|c|c|}
\hline Communication & Professional activity & Interaction with the students \\
\hline $\begin{array}{l}\text { "The voice is a means of communication, } \\
\text { of expressing feelings, our way of being, } \\
\text { of feeling..." (P3) } \\
\text { "It is part of our identity, it is very impor- } \\
\text { tant for communication... an important } \\
\text { means of communicating and interacting, } \\
\text { of learning, and interacting in different } \\
\text { aspects, right?" (P5) } \\
\text { "The voice is indispensable to me be- } \\
\text { cause it is how I express myself... It is a } \\
\text { means of reaching out to other people" } \\
(P 2)\end{array}$ & $\begin{array}{l}\text { "The voice has greater importance in my } \\
\text { life because it is associated with my ca- } \\
\text { reer, which is research; so, the voice is } \\
\text { what I work with..." (P4) } \\
\text { "The voice is one of the main instruments } \\
\text { one has to work with... It is with the voice } \\
\text { that I work as a professor". (P1) } \\
\text { "The means for me to work with... The voi- } \\
\text { ce is how I develop, how I can develop my } \\
\text { work...". (P3) }\end{array}$ & $\begin{array}{l}\text { "The voice is the means of communica- } \\
\text { tion with the student..." (P3) } \\
\text { "It is essential because it is through the } \\
\text { voice, through oral verbal language, that } \\
\text { we interact with the students and mediate } \\
\text { the learning process..." (P5) } \\
\text { "The voice to me is the main means of } \\
\text { communicating with my students, of ex- } \\
\text { posing my ideas..." (P4) }\end{array}$ \\
\hline
\end{tabular}

Figure 2. Participants' voice representation

In Figure 3, regarding the professors' perceptions concerning factors that lead to voice complaints, three subcategories were identified in their speech, namely: environmental, organizational, and personal factors. The environmental factors that stood out in their statements were the temperature and noise in the room, which was commonly mentioned by them: "The work setting is inhospitable, too hot, too large, too noisy; so I have to use my voice at maximum intensity all the time..." (P1). In the organizational factors, the excessive number of students and the lack of rest due to consecutive classes stood out: "The number of students, this is also a determining factor that I notice that changes how my voice behaves..." (P3). In the personal factors, aspects such as the inadequate use of the voice and allergies (flu, rhinitis) stood out: "I sometimes get the flu, lose my voice, and then laryngitis affects me..." (P2).

\begin{tabular}{|c|c|c|}
\hline Environmental factors & Organizational factors & Personal factors \\
\hline $\begin{array}{l}\text { "The work setting is inhospitable, too hot; } \\
\text { the environments are too large, too noisy; } \\
\text { so, I have to use my voice always at maxi- } \\
\text { mum intensity...". (P1) } \\
\text { "The work setting is not always clean, so I } \\
\text { suffer a lot; as I am allergic, I suffer a lot } \\
\text { with the dust in the classrooms, in my of- } \\
\text { fice, in the labs... Another thing that harms } \\
\text { me is noise. I don't know if the rooms have } \\
\text { adequate acoustic isolation; so, there is } \\
\text { too much external noise coming into the } \\
\text { classroom, so I have to raise my voice. } \\
\text { That is something that bothers me, and I } \\
\text { take notice of" (P2) } \\
\text { "An air conditioner that makes too much } \\
\text { noise, then you have to kind of compete } \\
\text { with it, you know, the electronic device, } \\
\text { you have to try to speak louder than that } \\
\text { noise..." (P4) }\end{array}$ & $\begin{array}{l}\text { "The number of students, right? That is } \\
\text { also a factor that changes, that I feel that } \\
\text { changes how my voice behaves..."(P3) } \\
\text { "I think the way the curriculum of the } \\
\text { courses I teach is structured; it impro- } \\
\text { ved since last year, but there have been } \\
\text { semesters when I taught ten consecutive } \\
\text { classes, with almost no break for lunch; } \\
\text { and this overloads the voice..." (P1) }\end{array}$ & $\begin{array}{l}\text { "We lack the training to use voice the best } \\
\text { way possible..." (P1) } \\
\text { "My occupation as a professor makes me } \\
\text { speak even louder and for longer, so this } \\
\text { makes me suffer a little, my voice suffers } \\
\text { a little because of this, I don't know, voice } \\
\text { timbre..."(P2) } \\
\text { "I sometimes get the flu, lose my voice, } \\
\text { and then laryngitis affects me..." (P2) } \\
\text { "I associate this hoarseness with the ina- } \\
\text { dequate use of voice, that is, speaking for } \\
\text { hours without intonating it right, without } \\
\text { the right pauses, without properly hydra- } \\
\text { ting the vocal cords..." (P4) }\end{array}$ \\
\hline
\end{tabular}

Figure 3. Factors leading to voice complaints 
The professors' perceptions regarding recommendations for healthily using the voice at work are shown in Figure 4. Based on their statements, three subcategories were identified: environmental, organizational, and personal factors. In the environmental factors, the highlights are the unnecessary use of air conditioning during class and the comfortable environments: "Not being necessary to use the air conditioning, which is noisy, distorts the voice and makes it tired..." (P3); "Work settings should be more comfortable, more pleasant... The professors who teach in these large rooms should be supplied with mechanical devices to aid them in teaching..." (P1). In the organizational factors, breaks for resting stood out, as well as class methodologies not requiring long expositions: "Less intense class periods, with longer breaks for the voice to rest..." (P1); "The type of class, you know; I propose many oral discussions, but many activities as well; so I mix both in the class, instead of making it a class in which only the professor speaks..." (P5). In the personal factors, drinking water and monitoring vocal intensity was highlighted: "I spend all day long teaching, and I keep my bottle of water with me... I exercise every day... I've been trying to lower my voice as I speak..." (P2).

\begin{tabular}{|l|l|l|}
\hline \multicolumn{1}{|c|}{ Environmental factors } & \multicolumn{1}{c|}{ Organizational factors } & \multicolumn{1}{c|}{ Personal factors } \\
\hline "Not being necessary to use the air condi- & "The small number of students makes & "Constantly hydrating the vocal cords, ri- \\
tioner, which is noisy and distorts the voi- & it possible to develop speech with more & ght?... The body posture also makes a dif- \\
ce, right, and makes it tired..." (P3) & quality... Having breaks, you can have a & ference..." (P4) \\
"The work settings should be more com- & break and give the voice some rest..." & "I spend all day long giving classes and I \\
fortable, more pleasant... The professors & (P3) & take my bottle of water with me... I exerci- \\
who teach in these large rooms should be & "Less intense class periods, with longer & se every day... I've been trying to lower my \\
supplied with mechanical devices to help & breaks for the voice to rest..." (P1) & voice..." (P2) \\
them teach..." (P1) & "The type of class, right; I have many oral "Always taking a bottle of water with me, \\
"I turn off the air conditioner to try to lower & discussions, but some activities as well, \\
my voice, you know..." (P2) & you know, to drink during class..." (P5) \\
& so I mix both in my class, you know, so it & \\
& is not a class in which only the professor \\
speaks..." (P5) & \\
\hline
\end{tabular}

Figure 4. Recommendations for healthily using the voice at work

\section{DISCUSSION}

Changes in voice quality may be related to various factors, such as the irregular vibration of the vocal folds, adduction or abduction problems, the flexibility of the mucosa, or tension of the intrinsic and extrinsic musculature of the larynx. The coordinated work of the larynx and vocal tract and the combination of these with inadequate adjustments are present in individuals with voice complaints and at risk of developing voice changes ${ }^{17}$. The high percentage of professors with voice complaints in this study (Table 2) corroborates the result of other studies ${ }^{1,17,18}$.

The data obtained in this research reveal more often voice complaints in female professors aged 20 to 39 years. The literature points out that, as one grows older, the efficiency of their voice decreases, and a series of structural changes may take place in the larynx, with a greater or smaller impact on their voice ${ }^{19}$.
However, this study's population reveals the opposite: the younger professors reported more complaints. This can be justified by their unawareness of voice issues in comparison to more experienced professors. The predominance of women in university faculty in this research confirms the findings of other studies ${ }^{20,21}$.

Such a predominance is explained by the broadening of the educational system, which started in Brazil in the mid-20 ${ }^{\text {th }}$ century. It considered teaching as a women's activity as it encompassed caring for others and was seen as a continuation of domestic activities".

Furthermore, females are considered more vulnerable to developing voice disorders when compared with males because of anatomo-physiological reasons. The female larynx characteristically has a posterior triangular fold and lower glottal proportion, making them more prone to the onset of voice changes. Besides these aspects, females have less hyaluronic acid on the surface of the vocal folds, which hinders 
their recovery from traumas. It is important to highlight that women attend health services more often than men, which can also be included in the justification of the women's having more voice symptoms ${ }^{17,22,23}$.

A study conducted with 88 middle and high school teachers analyzed voice symptoms and lifestyle factors. It found that $64.77 \%$ of the interviewees self-reported voice changes. Moreover, the literature reports that the voice problems appear after long years in the profession ${ }^{24}$ - which differs from the present study, whose finding was the opposite, as the professors with less time in the profession were the ones that most reported voice complaints.

The older and more experienced professors may have learned about vocal hygiene and become aware of their own voice, which might have helped them, in contrast with their younger and less experienced counterparts ${ }^{25}$. This can justify the findings in this study, as the population that most reported voice complaints in this research was the one who had been teaching for less time. It is essential to clarify that this is a limited comparison of studies because the present one analyzes higher education.

The workload is normally of great importance for the perception of a professors' working conditions. They are associated with both the poor quality of life and the presence of pathologies. In this study, the professors who most reported voice problems were those with the heaviest workloads. Hence, it confirms what is said in the literature and shows that indeed it is an issue that needs to be addressed in health promotion public policies for the professors ${ }^{1,17,19,20}$.

The professors' self-report of voice symptoms (Figure 1) shows that approximately $67.13 \%$ of them mentioned discomfort when speaking for long. This is due to the great demand for their voice, which in turn leads to incorrect use of the voice, especially in activities that require great effort, potentially resulting in a negative voice symptom ${ }^{1,19}$.

Other voice problems (Figure 1) reported by the professors were related to unawareness of how to use the voice, modifications in the voice throughout the day, hoarseness, weak voice, effort to speak, and fatigue when speaking. The symptoms reported by the subjects are compatible with those described in the literature that verified such complaints in professors ${ }^{22,26}$. These symptoms reflect the combination of various factors related to the working conditions and the professors' perception of the exposure to the environment and workload, which can cause voice symptoms and eventually dysphonia ${ }^{1}$.

The self-perception of voice and of factors that cause voice disorders is very important, whereas these professionals' unawareness regarding the voice make them little careful with it while, at the same time, they do not seek for help ${ }^{13,27}$. In this context, the interviews with some professors enabled their perception to be understood regarding voice representation, factors leading to voice complaints, and recommendations regarding the use of voice.

For the professors, the voice is important because it is what they use to communicate and interact with other people, besides being what they work with. Knowing about their voice and its importance as a teaching resource is greatly relevant for academic life, as shown in research that approached this theme ${ }^{4,13}$. Nevertheless, it is common to see studies revealing these professionals' lack of knowledge about the voice, which makes them little careful with $\mathrm{it}^{3,28}$.

For part of the professors interviewed, the work setting (Figure 3 ) is noisy, dirty, and with an inadequate temperature. The intense noise most of the time forces them to raise the voice to communicate, potentially causing important changes, such as dysphonia ${ }^{29,30}$. The inadequate temperature and the dust present in the room are factors that bother the professors; these circumstances have been investigated by speechlanguage-hearing pathologists for some time $20,31,32$.

The literature shows that the cause of dysphonia is multifactorial28; the work organization in some ways can contribute to its onset. Regarding the organizational factors that lead to voice complaints, the professors reported the large number of students and the lack of breaks in between classes as the most unsatisfactory factors. The professors' self-report in this research is confirmed in the literature, which shows that the number of students and the lack of rest are directly related to the educators' dysphonia and poor quality of life. Nevertheless, it should be highlighted that the activities of public university professors are not exclusively related to teaching; they have other duties that do not require their voice as much ${ }^{19}$.

The professors' statements regarding personal factors that lead to voice complaints highlight aspects such as allergies and the unawareness about how to use the voice. That these can influence the onset of voice complaints is confirmed by the literature ${ }^{3,13,28}$.

The professors participating in this study made many comments regarding the healthy use of voice at 
work. Among the aspects mentioned, they highlighted not using the air conditioner, having comfortable environments, having breaks to rest their voice, not planning expositive-only classes, drinking water, and monitoring their voice intensity. These aspects contradict what they had said about not knowing how to use their voice properly - it shows indeed a brief understanding of the factors related to the healthy use of voice. Also, it confirms research equally involving university professors, which identified that these professionals have a perception of how they should care for their voice and how to handle it at work ${ }^{13}$.

This research shows that the population studied reports a high percentage of voice complaints and has good voice perception. This indicates that the main measures to improve the working conditions of the professors investigated are related to the work setting and organization. However, it is expected that programs be developed to make this category more aware of their voice, as a good part of them stated not knowing much about it. This is particularly important given that for the professor the voice is their means of communication and needs to be in good condition for them to carry out their duties $3,28,29$.

\section{CONCLUSION}

In this study, many reports of voice symptoms were observed in higher education professors. The professors' testimonies revealed that they know how to take care of their voice and are aware of what happens with it. For them, the work setting and organization can lead to an unhealthy voice. Hence, they demonstrate that they have a good perception of the factors that cause voice complaints.

\section{REFERENCES}

1. Fillis MMA, Andrade SM, González AD, Melanda $\mathrm{FN}$, Mesas AE. Frequência de problemas vocais autorreferidos e fatores ocupacionais associados em professores da educação básica de Londrina, Paraná, Brasil. Cad. Saúde Pública. 2016;32(1):e00026015.

2. Brasil. Ministério da Saúde. Secretaria de Vigilância em Saúde. Departamento de saúde Ambiental e Saúde do Trabalhador. Distúrbio de Voz Relacionado ao Trabalho. Brasília, 2018.

3. Fabricio MZ, Kasama ST, Martinez EZ. Qualidade de vida relacionada á voz de professores universitários. Rev. CEFAC. 2009;12(2):280-7.
4. Rezende Netto B. Conceptions of teacher of IES for articulated communicative and expressive development on evaluation of students on this performance. Rev. CEFAC. 2013;15(1):25-39.

5. Alves LP, Araújo LTR, Xavier Neto JA. Prevalência de queixas vocais e estudo de fatores associados em uma amostra de professores de ensino fundamental em Maceió, Alagoas, Brasil. Rev. brasileira de Saúde ocupacional. 2010;35(121):168-75.

6. Almeida LNA, Lopes LW, Costa DB, Silva EG, Cunha GMS, Almeida AAF. Vocal and emotional features of teachers and non-teachers with low and high anxiety. Audiol., Commun. Res. 2014;19(2):179-85.

7. Choi-Cardim K, Behlau M, Zambon F. Sintomas vocais e perfil de professores em um programa de saúde vocal. Rev. CEFAC. 2010;12(5):811-9.

8. Dragone MLOS. Programa de Saúde Vocal para educadores: ações e resultados. Rev. CEFAC. 2011;13(6):1133-43.

9. Luchesi KF, Mourão LF, Kitamura S, Nakamura HY. Problemas vocais no trabalho: prevenção na prática docente sob a óptica do professor. Rev. Saúde e Sociedade. 2009;18(4):673-81.

10. Cielo CA, Ribeiro VV, Bastilha GR. Spectrographic voice measures, vocal complaints and occupational data of elementary school teachers. Distúrb. Comum. 2015;27(2):299-308.

11. Souza CL, Carvalho FM, Araújo TM, Reis EJFB, Lima VMC, Porto LA. Fatores associados a patologias de pregas vocais em professores. Rev. Saúde Pública. 2011;45(5):914-21.

12. Lima JP, Ribeiro VV, Cielo CA. Vocal symptoms, quantity of speech degree and loudness of voice in teachers. Distúrb. Comun. 2015;27(1):129-37.

13. Servilha EAM, Costa ATF. Knowledge about voice and the importance of voice as an educational resource in the perspective of university professors. Rev. CEFAC. 2015;17(1):13-26.

14. Servilha EAM, Arbach MP. Queixas de saúde em professores universitários e sua relação com fatores de risco presentes na organização do trabalho. Distúrb. Comum. 2011;23(2):181-91.

15. Sapir S, Keidar A, Mathers-Schmidt B. Vocal attrition in teachers: survey findings. J Disord Commun. 1993;28(2):177-85.

16. Campos CJG. Método de análise de conteúdo: ferramenta para a análise de dados qualitativos no campo da saúde. Rev Bras Enferm. 2004;57(5):611-4. 
17. Souza LBR, Gurlekian JA, Sabino APM, Pernambuco LA, Santos MM. Avaliação do risco vocal em professores do ensino fundamental. Rev. Ciênc. Méd. Biol. 2014;13(10):18-23.

18. Houtte EV, Claeys S, Wuyts F, Van LK. the impact of voice disorders among teachers: vocal complaints, treatment-seeking behavior, knowledge of vocal care, and voice-related absenteeism. Rev Soc Bras Fonoaudiol. 2011;16(2):240-1.

19. Ferracciu CCS, Santos LVA, Texeira LR, Almeida MS. Coping strategies and profile voice activities participation in teachers of public schools with and without voice disorders. Rev. CEFAC. 2015;17(4):1184-94.

20. Pereira EF, Texeira CS, Silva-Lopes RAA. O trabalho docente e a qualidade de vida dos professores na educação básica. Rev. Saúde Pública. 2014;16(2):221-31.

21. Devadas U, Bellur R, Maruthy S. Prevalence and risk factors of voice problems among primary school teachers in India. J Voice. 2017;31(1):117. e1-117.e10 0892-1997.

22. Pizolato RA, Mialhe FL, Cortellazzi KL, Ambrozano GMB, Cornacchioni Rehder MIB, Pereira AC. Evaluation of risk factors for voice disorders in teachers and vocal acoustic analysis as an instrument of epidemiological assessment. Rev. CEFAC. 2013;15(4):957-66.

23. Gomes R, Nascimento EF, Araújo FC. Why do men use health services less than women? Explanations by men with low versus higher education. Cad. Saúde Pública. 2007;23(3):565-74.

24. Caporossi C, Ferreira LP. Sintomas vocais e fatores relativos ao estilo de vida em professores. Rev. CEFAC. 2011;13(1):132-9.

25. Costa V, Prada E, Roberts A, Cohen S. Voice disorders in primary school teachers and barriers to care. J Voice. 2012;26(1):69-76.

26. Teixeira LN, Rodrigues AL, Silva FM, Silveira RCP. As possíveis alterações no estilo de vida e saúde de professores. R. Enferm. Cent. O. Min. 2015;5(2):1669-83.

27. Morais EPG, Azevedo RR, Chiari BM. Correlação entre voz, autoavaliação vocal e qualidade de vida em voz de professoras. Rev. CEFAC. 2012;14(5):892-900.

28. Lima-Silva MFB, Ferreira LP, Oliveira IB, Silva MAA, Ghirardi ACAM. Distúrbio de voz em professores: autorreferência, avaliação perceptiva da voz e das pregas vocais. Rev. Soc. Bras Fonoaudiol. 2012;17(4):391-7.

29. Rabelo ATV, Guimarães ACF, Oliveira RC, Fragoso LB, Santos JN. Evaluation and perception of teachers on the effects of sound pressure level in the classroom. Distúrb. Comun. 2015;27(4):715-24.

30. Munier C, Farrell R. Working conditions and workplace barriers to vocal health in primary school teachers. J Voice. 2016;30(1):127.e31-127.e41.

31. Abo-Hasseba A, Waaramaa T, Alku P, Geneid A. Difference in voice problems and noise reports between teachers of public and private schools in upper Egypt. J Voice. 2017;31(4):508.e11-508.e16.

32. Servilha EAM, Correia JM. Correlation between environment, work organization conditions, voice symptoms self-reported by university professors and speech-language pathology assessment. Distúrb. Comum. 2014;26(3):452-62. 